\title{
An Interdisciplinary Perspective on the Value of Envy
}

\author{
Jens Lange ${ }^{1}$ (i) $\cdot$ Sara Protasi ${ }^{2}$
}

Accepted: 4 April 2021/Published online: 19 April 2021

(C) The Author(s) 2021

\begin{abstract}
The public and scholars alike largely consider envy to be reprehensible. This judgment of the value of envy commonly results either from a limited understanding of the nature of envy or from a limited understanding of how to determine the value of phenomena. Overcoming this state requires an interdisciplinary collaboration of psychologists and philosophers. That is, broad empirical evidence regarding the nature of envy generated in psychological studies must inform judgments about the value of envy according to sophisticated philosophical standards. We conducted such a collaboration. Empirical research indicates that envy is constituted by multiple components which in turn predict diverse outcomes that may be functional for the self and society. Accordingly, the value of envy is similarly nuanced. Sometimes, envy may have instrumental value in promoting prudentially and morally good outcomes. Sometimes, envy may be noninstrumentally prudentially and morally good. Sometimes, envy may be bad. This nuanced perspective on the value of envy has implications for recommendations on how to deal with envy and paves the way toward future empirical and theoretical investigations on the nature and the value of envy.
\end{abstract}

Keywords Envy · Benign and malicious envy $\cdot$ Instrumental and non-instrumental value Prudential and moral value

\section{Introduction}

Envy is commonly viewed as reprehensible. In the media, writers portray envy as an emotion that humans should ideally suppress or transmute (e.g., Razzetti 2018). Similarly, religious leaders, such as pope Francis, see envy as the root of evil (Glatz 2014). Pope Francis' viewpoint is in line with the Christian tradition to explicitly

Jens Lange

lange.jens@outlook.com

1 University of Hamburg, Von-Melle-Park 5, 20146 Hamburg, Germany

2 University of Puget Sound, Tacoma, WA, USA 
condemn envy as a deadly sin, an emotion responsible for Cain slaying his brother or the Romans torturing and murdering Jesus (Aquaro 2004). Beyond folk psychological and religious perspectives, scholarly approaches to envy also cast envy in a negative light. Some sociologists identify envious motives in numerous different kinds of crimes such as assassination, sabotage, and harassment (Schoeck 1969). Relatedly, historians and psychologists have identified envy to be a central factor behind persecutions of the Jews by the Nazis, envious of the supposed power and influence they ascribed to them (Glick 2002; Smith 2014). Extensive early reviews covering broad empirical evidence indeed suggested that envy is fueled by unjust resentment and fosters excessive hostility and personal unhappiness (e.g., Miceli and Castelfranchi 2007; Smith and Kim 2007), implying the conclusion that envy is, by and large, dispensable from the set of human emotions.

However, such a negative evaluation is dependent on an incomplete understanding of envy's complex emotional nature. We are going to argue that the mainstream view skewed the evaluation of envy, affecting not only what kind of questions researchers posed, but also how they interpreted evidence (for related discussions see Inbar and Lammers 2012; Colombo et al. 2016; but see also Mattes 2019). That is, folk perceptions and religious prejudices about envy may have steered empirical research into confirming the negative stance, neglecting the nuanced ways in which envy can manifest.

Indeed, a few perspectives diverged from the common view and emphasized that envy can also foster non-hostile behaviors that are acceptable (e.g., Van de Ven 2016; Lange et al. 2018a) or even valuable (e.g., La Caze 2001; Thomason 2015). In line with these perspectives, we show that envy cannot be fully understood if it is empirically investigated without questioning traditional assumptions about the value of envy. Discarding the entrenched belief that envy is reprehensible provides a new perspective on envy. And a refined perspective on the nature of envy through empirical research in turn updates the common perspective on the value of envy.

We suggest that a comprehensive and successful re-evaluation of the value of envy requires two elements. First, widespread views on envy need to be updated by broad empirical evidence gathered from diverse samples. To achieve this goal, researchers must constantly reconsider their underlying cultural norms, religious beliefs, and linguistic practices, increasing awareness for how socially situated their research is. Second, research on the value of envy ought to be an interdisciplinary collaboration between social scientists and philosophers. Psychologists, anthropologists, and sociologists bring different perspectives to the study of emotions, but they all share a descriptive approach, that is, they aim to study phenomena as they are. Philosophers, ethicists in particular, are interested in normativity, that is, they study how things ought to be. Because of their normative approach, philosophers have developed a more nuanced vocabulary to speak about the value of phenomena. Yet, they often develop their prescriptions in the absence, or with only cursory knowledge, of the empirical evidence that is discussed in the social sciences. Our goal is to engage in precisely this kind of fruitful collaboration, in order to show what the conventional wisdom on the value of envy gets wrong, and why it gets some things right. We hope that an empirically informed and philosophically sophisticated approach to the value of envy can serve as a model for inquiries on other emotions. 


\section{The Nature of Envy}

Some characteristics of envy are uncontroversial. All approaches to envy agree that it involves three elements (for reviews see Heider 1958; Miceli and Castelfranchi 2007; Smith and Kim 2007; D'Arms 2018), namely two parties (typically two persons) and a quality, achievement, or possession (i.e., the envy object). One party has the object, putting the other party at a perceived comparative disadvantage. The disadvantaged party (i.e., the envier) experiences negative affect in light of the inferiority vis-à-vis the advantaged party (i.e., the envied person), if the object refers to a domain of high personal relevance to the envier (Salovey and Rodin 1984). The difference between the envier and the envied person need not be large. Quite the contrary, as is already discussed by Aristotle (1929), envy is experienced mostly toward similar others (Henniger and Harris 2015), with whom competition is reasonable (Ben-Ze'ev 2002), and not towards others who exceed the envier by a large margin. That is, envy is targeted at an object for which the envier can easily imagine a counterfactual world in which the situation had been different (Crusius and Lange in press; Teigen 1997; Coricelli and Rustichini 2009; Van de Ven and Zeelenberg 2015). Given this easily imaginable alternative reality, the presumed primary goal of the envier is to level the difference between them and the envied person (Sayers 1947).

Beyond these agreed-upon characteristics of envy, the nature of envy is part of an ongoing debate. Early contributions in philosophy and psychology emphasized the hostility of envy. For instance, envy was conceptualized as resulting from subjectively undeserved inferiority (Ben-Ze'ev 2002), additionally involving hostility and resentment toward the envied person (Smith and Kim 2007), as well as hopelessness and illwill (Miceli and Castelfranchi 2007). In line with this theoretical conceptualization, research indicates that envy leads to deception (Moran and Schweitzer 2008), social loafing (Duffy and Shaw 2000) as well as social undermining in groups (Duffy et al. 2012), victimization of high performers (Kim and Glomb 2014), a willingness to give up personal resources to reduce the envied person's resources (Zizzo and Oswald 2001), and generalized antisocial (Behler et al. 2020) or unethical behavior (Gino and Pierce 2009). These outcomes of envy serve to level the difference between the envier and the envied person by harming the envied person's position.

Despite this focus on hostility in early empirical research on envy, early theoretical contributions in philosophy and psychology already emphasized that envy also relates to self-improvement and emulation of the envied person (e.g., Aristotle 1929; Parrott 1991). Indeed, research that identified components of envy often found components such as longing, motivation to improve (Parrott and Smith 1993), and even somewhat positive thoughts about the envied person (Salovey and Rodin 1986). Potentially driven by these components, envy positively predicted performance increments in the work context (Schaubroeck and Lam 2004; Cohen-Charash 2009), increases in consumption (Belk 2011), or desire for the envy object (Crusius and Mussweiler 2012). These outcomes of envy serve to level the difference between the envier and the envied person by improving the envier's position. However, in line with the widespread condemnation of envy, such findings were commonly discarded as not describing envy proper (Smith and Kim 2007) but an emotion akin to admiration (Silver and Sabini 1978). 


\subsection{The Multi-Componential Nature of Envy}

Recent research refutes the dismissal of non-hostile varieties of envy and supports a more nuanced view of envy. As a starting point, these approaches emphasize that the primary goal of the envier is to level the difference between them and the envied person (for reviews see Van de Ven 2016; Crusius and Lange 2017; Lange et al. 2018a). By putting emphasis on the goal that underlies envy, these approaches shift the focus toward a functional perspective on envy and away from a traditional approach influenced by moral condemnation (for an adversarial collaboration discussing previous and recent approaches, see Crusius et al. 2020). This shift allows to incorporate components and outcomes of envy that disprove the supposed reprehensive character of envy. A fully developed functional account, therefore, first requires a comprehensive theory of the multi-componential nature of envy.

To unravel the complex nature of envy, the functional perspective disentangles different components of envy (Lange et al. 2018c). In line with previous conceptualizations (Tai et al. 2012), the evidence indicates that envy involves painful feelings. In particular, in response to the social comparison with the envied person, the envier experiences tormenting inferiority and depressive feelings (Lange et al. 2018c). These painful feelings positively predict two qualitatively independent sets of components: benign and malicious envy.

Benign envy is partly constituted by feelings, cognitions, and motivations directed at improving the envier's position, and does not involve any hostile feelings (Lange et al. 2018c). Specifically, benign envy involves desire for the object, motivation to improve, and the intention to emulate the other person. Research shows that benign envy correlates with more positive feelings toward the envied person (Van de Ven et al. 2009), attention toward both the envied person and the object as well as means to obtain it (Crusius and Lange 2014), and actual performance increases (Van de Ven et al. 2011a; Lange and Crusius 2015a; Khan et al. 2017; Salerno et al. 2019) to such an extent that potential risks are ignored (Kwon et al. 2017). Moreover, evidence indicates that people with a higher disposition to experience benign envy accomplish better academic and athletic achievements than people with a lower disposition (Lange and Crusius 2015b; Sawada and Fujii 2016), have higher well-being (Briki 2019), and are viewed more positively by their peers (Lange et al. 2016). Thus, benign envy primarily reduces the difference between the envier and the envied person by leveling up, that is, by reaching the envied person's level.

Malicious envy is partly constituted by feelings, cognitions, and motivations directed at harming the envied person's position (Lange et al. 2018c). Specifically, malicious envy involves hostile feelings and motivation to be aggressive toward the envied person. Research shows that malicious envy correlates with more negative feelings toward the envied person (Van de Ven et al. 2009), attention toward the envied person at the expense of the envy object (Crusius and Lange 2014), and actual harming behavior (Lange and Crusius 2015a; Van de Ven et al. 2015; Lange et al. 2018c; Yusainy et al. 2019). Thus, malicious envy primarily reduces the difference between the envier and the envied person by leveling down, that is, by bringing the envied person to the envier's level.

Even though benign and malicious envy are largely constituted by partly opposing components and their presence predicts different outcomes, they also share various 
characteristics. Studies that manipulated benign and malicious envy supported the hypothesis that they have the same levels of accompanying negative affect (Crusius and Lange 2014; Lange and Crusius 2015b; Lange and Crusius 2015a; Lange et al. 2018c). Moreover, a dispositional inclination to engage in social comparisons predicted higher dispositional benign and malicious envy (Lange and Crusius 2015b; Lange et al. 2016). These characteristics distinguish benign and malicious envy from similar emotions such as admiration and resentment. Admiration is characterized only by positive affect and both admiration and resentment rely less on comparative processes (Van de Ven et al. 2009; Crusius and Lange 2014; Protasi 2019). Furthermore, if benign and malicious envy have partly opposing and partly shared characteristics, this may explain why they are largely uncorrelated at both the state (Lange et al. 2018c) and trait level (Lange and Crusius 2015b).

Importantly, this multi-componential perspective on envy was corroborated in a methodologically diverse set of studies. Some studies relied on languages that have different words for benign and malicious envy, such as Dutch, German, or Urdu (Van de Ven et al. 2009; Crusius and Lange 2014; Khan et al. 2017). They showed different response profiles on various defining components of benign and malicious envy, when participants recalled corresponding emotional situations. But also in languages with only one word for envy, such as English or Spanish, responses to various items assessing a diverse set of envy components supported the conclusion that participants' envy stories include qualitatively different kinds, mapping onto benign and malicious envy (Van de Ven et al. 2009; Falcon 2015). Other studies analyzed responses to researcher-generated sets of items measuring dispositional or episodic envy and found that two factors explain the data best (Cohen-Charash 2009; Lange and Crusius 2015b; Sterling et al. 2017; Kwiatkowska et al. 2018). These factors were consistent with conceptualizations of benign and malicious envy. Finally, even when items were not generated by the researchers themselves, but by naïve participants or experts on envy with various backgrounds, analyses of the structure of these items led to multicomponential solutions, including benign and malicious envy, alongside painful feelings as organizing factors (Lange et al. 2018c).

Whether envy manifests in shades of its benign or malicious form depends on additional variables. Many emotion theories argue that the unfolding of emotion episodes depends on appraisals of the situation (Ellsworth and Scherer 2003; Clore and Ortony 2013). For envy, research emphasizes the role of perceptions of personal control, that is, subjective beliefs about whether the person can actively change certain aspects of the situation. Theorizing and evidence suggest that when enviers perceive control to obtain the object themselves, envy is more likely to manifest in its benign form (Van de Ven et al. 2012; Lange et al. 2016; Protasi 2016). But also malicious envy may need certain perceptions of control, especially perceptions of control to take the object away from the envied person (Protasi 2016). Yet, the correlation with perceptions of control is stronger for benign envy (Lange et al. 2016). Perceived lack of control within benign envy itself may also lead to different manifestations of envy, insofar as self-improvement may be conceived as attainable or unattainable (Protasi 2016).

Next to control, research emphasizes the role of perceptions of deservingness of the envied person's advantage. Theorizing and evidence suggest that when enviers appraise the envied person's advantage as undeserved, envy is more likely to manifest in its 
malicious form (Van de Ven et al. 2012; Lange and Crusius 2015a; Lange et al. 2016). The same studies imply that, to a lesser extent, when enviers appraise the envied person's advantage as deserved, envy is more likely to manifest in its benign form. Furthermore, other perspectives suggest that perception of deservingness may be mediated by focus of concern, defined as what the envier cares about (Protasi 2016; Protasi 2021). Specifically, if the envier cares about leveling down the envied person and is thus more concerned with the envied person's superiority as opposed to obtaining the envy object, then they are likely to see the envied person with hostility and to rationalize their success as undeserved - dislike for the envied person might make an appraisal of undeservingness more likely.

If appraisals of personal control and deservingness play a central role in determining the manifestation of envy, then variables affecting the appraisals should similarly shape envious responses. In line with this hypothesis, variables correlating with higher appraisals of personal control predicted higher dispositional and state benign envy. Examples of such variables are stable self-esteem (Smallets et al. 2016; but see also Vrabel et al. 2018), assertive facets of narcissism (Lange et al. 2016), increased hope for success (Lange and Crusius 2015b; Lange et al. 2018c), or envied persons' signals that their success was based on invested effort (Lange and Crusius 2015a). Moreover, variables correlating with lower appraisals of deservingness predicted higher dispositional and state malicious envy. Examples of such variables are aggressive facets of narcissism (Lange et al. 2016) or envied persons' signals that their success was based on natural talent (Lange and Crusius 2015a). Furthermore, fragile self-esteem predicted higher malicious envy (Smallets et al. 2016) as did fear of failure (Lange and Crusius 2015b; Lange et al. 2018c), which predicted lower perceptions of control to obtain the object. Notably, the evidence regarding the influence of personal control and deservingness is partly mixed, requiring more research on central appraisals shaping benign and malicious envy (Crusius et al. 2020), also taking other variables, such as the focus of concern, into account (Protasi 2016; Protasi 2021).

Thus, research indicates that envy is multi-componential. It is constituted by painful feelings, and the different feelings, cognitions, and motivations that constitute benign and malicious envy. This conclusion is based on methodologically diverse studies from different countries. Moreover, perceptions of personal control and deservingness of the envied person's advantage contribute to whether envy is more likely to develop into its benign or malicious form. With the multi-componential theory of envy at hand, it is possible to develop a functional approach to envy.

\subsection{A Functional Approach to Envy}

Emotions contribute to the regulation of social relationships and social hierarchies - they have social functions (Keltner and Haidt 1999; Van Kleef 2009; Fischer and Manstead 2016). The social function of a particular emotion depends on the social-relational goal it motivates the agent to achieve. For instance, anger toward another person motivates to attain a better outcome for the angry person by forcing, for instance, the other person to change. Anger is then socially functional if it causes confrontational behaviors that are successful in accomplishing the goal (Fischer and Roseman 2007). 
If the goal of envy is indeed to reduce the difference between the envier and the envied person (Sayers 1947; Van de Ven et al. 2009), it may contribute to the regulation of social hierarchies. Social hierarchies can be based on either prestigepeople attain status in the eyes of others by achieving success as well as sharing skills and know-how - or dominance - people attain status in the eyes of others by aggressive intimidation and the elicitation of fear (Henrich and Gil-White 2001; Cheng et al. 2013; Maner and Case 2016). Benign envy may contribute to the regulation of prestige. This is because prestigious others should convey that self-improvement is possible and attaining prestige similarly relies on self-improvement and social skills. Malicious envy may contribute to the regulation of dominance. This is because dominant others typically oppress people, implying that inferior others will hold grudges against them, and attaining dominance requires willingness to engage in hostile action. If the envy forms would indeed serve the social function to regulate the envier's relative standing, they also solve the envier's initial problem of an unflattering comparison to another person. That is, the envier no longer has a relatively low status, which should reduce the painful experience elicited by the comparison. Next to being socially functional, envy thereby also serves the intrapersonal function of regulating the painful experience.

Evidence is in line with these hypotheses. Studies support the idea that a superior person who signals prestige elicits the inferior person's benign envy, and a superior person who signals dominance elicits the inferior person's malicious envy (Lange and Crusius 2015a; Lange and Boecker 2019). In these studies, the inferior person's benign envy then led to emulation of the superior person and malicious envy led to relationshipdeteriorating effects. Furthermore, people with a higher motivation to attain prestige or dominance tend to have a higher dispositional inclination to experience the respective envy forms and also respond with them in concrete comparison situations (Lange et al. 2019). Moreover, facets of narcissism that map onto striving for prestige or dominance similarly correlate with trait and state benign and malicious envy, respectively (Lange et al. 2016). The latter study further indicated that inclinations to experience the envy forms correlate with an altered perception of the envier in the eyes of peers. That is, the tendency to experience benign envy correlates with the envier's social potency as perceived by others (indicative of prestige), and the tendency to experience malicious envy correlates with the envier's social conflict as perceived by others (indicative of dominance). In line with these findings, benign envy correlates with a higher standing in the occupational hierarchy at work, even if this requires to engage in deceptive strategies such as concealing true intentions, using ingratiation, or telling others what they want to hear to gain their compliance (Lange et al. 2018b). Thus, envy has a social function in that it contributes to the regulation of social status and it also serves the intrapersonal function of reducing the pain that originally resulted from the unfavorable standing as compared to the other person (Fiske 2010; Belk 2011; Crusius and Lange 2017).

Yet this is not to say that envy will always be functional. Even if emotions can serve social and intrapersonal functions, they may manifest in various ways in specific contexts. Many manifestations of emotions in social and individual situations will probably turn out to be dysfunctional (e.g., Fischer and Manstead 2016). For instance, it is easily imaginable that benign envy may activate outcomes that do not lead to eventual success in the long-run, despite the enviers motivation to achieve it. Or malicious envy could lead to outcomes that fail to harm the envied person's position. Accordingly, the functionality of envy depends on contextual and personal variables. 


\subsection{Summary of the Nature of Envy}

In sum, recent research provides an empirically grounded, nuanced perceptive on the nature of envy. The evidence indicates that envy is best defined as an emotion that involves burdensome pain, as well as feelings, cognitions, and motivations directed at improving the envier (i.e., benign envy) or harming the envied person (i.e., malicious envy). Multiple variables affect how an envy episode unfolds, among them are appraisals of personal control to obtain the object or to take the object from the envied person and appraisals of deservingness of the envied person's advantage. The manifestations of envy contribute to resolving the original problem that elicited the pain, namely the difference between the envier and the envied person. From a social perspective, envy is functional for leveling status differences in terms of prestige or dominance and improves the envier's relative standing. However, it may well happen that the outcomes of envy turn out to be dysfunctional in a specific context. The functional perspective on envy is free of inherent value judgments about envy, but it can nevertheless inform a philosophically sophisticated approach to the value of envy. This is where we turn next.

\section{The Value of Envy}

Just like the nature of envy, the value of envy is part of ongoing debates in philosophy and psychology, while the debates proceeded largely independent of each other. In philosophy, most contributions, historical and contemporary, have argued that envy is morally bad (e.g., Aristotle 1925; Roberts 1991; D’Arms and Kerr 2008), even though it may be a fitting response to a situation (D'Arms and Jacobson 2000). Most of the philosophical approaches have thus relied on a conceptualization of envy as primarily malicious. When they have considered the possibility of multiple ways of conceptualizing envy and its variables, they have done so by overlooking relevant empirical evidence, and arguing that non-malicious forms of envy count as envy only superficially (Taylor 2006).

A few authors have noticed that envy is not always related to harming intentions. They have argued that envy is potentially morally neutral (Ben-Ze'ev 2002), excusable (Bankovsky 2018), reasonable (Green 2013), or even morally valuable when it concerns envied persons' undeserved advantages, leads to self-improvement, or addresses social inequalities (La Caze 2001), or because it shows that the envier cares about objects that contribute to a worthwhile life, a key responsibility of a moral agent (Thomason 2015). But even these more envy-friendly perspectives have not consistently or extensively engaged with the empirical literature, often supporting empirical speculations with only anecdotal evidence.

In psychology, similar standpoints on the value of envy exist. Early theoretical approaches conceptualized envy as an emotion that is constituted by hostility and illwill, which stem from comparative inferiority for which the envied person is not necessarily responsible (Smith and Kim 2007). Therefore, envy was classified as detestable (Miceli and Castelfranchi 2007). When research on benign and malicious envy emerged, a common criticism was that the two envy forms simply tease apart the constructive and destructive outcomes of envy (Cohen-Charash and Larson 2017). 
Specifically, the criticism was that benign envy includes only constructive outcomes and is therefore socially desirable and easily admitted to others. In contrast, malicious envy includes only destructive outcomes and is therefore socially undesirable and usually disguised. However, other research shows that benign envy can foster socially undesirable outcomes such as Machiavellian intentions (Lange et al. 2018b) or overconsumption (Belk 2011) and that malicious envy can foster socially desirable outcomes such as outcome-focused goal pursuit (Salerno et al. 2019) or social punishment of arrogant high-achievers (Lange and Boecker 2019). In light of these findings, research in psychology now largely recommends refraining from value judgments about envy (Crusius et al. 2020). Yet, much like a philosophical approach is limited which engages only superficially with empirical evidence, so is a psychological approach which refrains from a thoughtful value assessment.

In sum, even though the debates in philosophy and psychology contributed to research on the value of envy, they are also limited. On the one hand, the debate in philosophy has been informed by sophisticated standards on which to evaluate the value of envy, yet it has lacked empirically grounded research. On the other hand, the debate in psychology has been informed by empirically grounded research, yet it has lacked sophisticated standards on which to evaluate the value of envy. Combining strengths of both approaches can consequentially illuminate the discussion. To achieve this goal, we need to discuss different dimensions on which to judge the value of envy.

\subsection{Dimensions for Judging the Value of Envy}

The empirically derived functional approach to envy emphasizes that it may primarily help the individual to solve intrapersonal and interpersonal tasks. More specifically, the components of envy are instrumental in triggering certain outcomes that contribute to the envier's well-being and social relationships. For instance, it may not be helpful to just desire the envy object (e.g., a possession), but this desire can spur various behaviors directed at obtaining the envy object (e.g., buying the possession) and thereby be functional for alleviating the painful inferiority the envier experiences.

In light of envy's functionality, it may seem straightforward to evaluate envy as instrumentally valuable, but the matter is more complicated for two reasons. First, even though evidence supports the conclusion that envy can be functional under certain conditions, its outcomes may sometimes turn out to be dysfunctional. That is, just because envy predicts efforts to regulate the envier's social status, this is not to say that all these efforts will always be successful. Therefore, the conditions that can render envy and its outcomes instrumentally good need to be investigated systematically. Relatedly, just because envy will often be functional, this is not to say that all value of envy boils down to instrumental value. Functional benefits are just one facet of the overall experience of envy. Hence, it is certainly possible that envy also has noninstrumental value, which we here define as being valuable for its own sake.

Second, we need to ask: envy is instrumentally valuable to whom? What is valuable to an individual's well-being can be detrimental to the well-being of someone else who is affected by the individual's actions, or by the community as a whole. An evil torturer who feels benign envy toward a more experienced torturer will be motivated to improve their torture skills. According to an amoral perspective which refrains from talking about value, we should say that this kind of envy, which motivates the envier to 
become better at their job, and thus to ascend in the social hierarchy (e.g., the person gets promoted and allowed to torture more prisoners), is accompanied by a boost in self-esteem and causes a genuine improvement in their material and emotional wellbeing. But this is a horrific thing to say.

There are at least two dimensions we need to take into account. Specifically, we assume a widely-shared distinction between prudential and moral value. A classical way of making the distinction derives from Henry Sidgwick's contrast between rational prudence, which aims at one's personal well-being, and rational benevolence, which takes into account the good of everyone else as much as one's own. Moral badness and goodness, in this picture, are assessed from "the point of view [...] of the universe" (Sidgwick 1967; p.382).

This distinction holds beyond rationalist approaches to ethics and can be found in some form or another in very different philosophical traditions. For instance, the sentimentalist David Hume draws a similar distinction between prudence and morality when he writes: "I am more to be lamented than blamed, if I am mistaken with regard to the influence of objects in producing pain or pleasure, or if I know not the proper means of satisfying my desires. No one can ever regard such errors as a defect in my moral character" (Hume 1969).

Such a conceptual distinction is maintained even in frameworks where prudence is extensionally conceived of as a subset of morality. For instance, contemporary virtue ethicists would argue that, for the virtuous agent, if something is morally bad, then it is also prudentially bad (e.g., McDowell 1979; Hursthouse 1999). But even for such theories, distinguishing between the prudential and moral value of envy is possible, and crucial for coping with envy productively.

Prudential and moral value evidently come apart in the torturer case. The torturer's personal well-being might improve, but the well-being of the victims clearly decreases. Such a distinction may also occur in envy. Therefore, when considering the value of envy, we need to distinguish between prudential and moral value as well as instrumental and non-instrumental value.

\subsection{The Value of Envy}

We propose to consider the value of envy alongside multiple pathways a person can take. Depending on which dimensions of value one considers and under which conditions one looks at envy and its consequences, the evaluation of envy will change. The structure depicted in Fig. 1 metaphorically represents the possible pathways that lead to different evaluations of envy. Hence, a multi-componential, functional account of envy allows deriving a nuanced perspective on the value of envy.

Along the first pathway, the functional approach to envy predicts that envy may have instrumental value, insofar as it brings about specific outcomes that a person would evaluate to be good in one of three ways. First, envy may have both prudential and moral instrumental value. For benign envy, evidence indicates that it relates to improvement motivation (Lange et al. 2018c), which may translate into actual improvement (Lange and Crusius 2015b). Such benignly envious efforts correlate with higher well-being of enviers and increases in flourishing over time (Briki 2019; $\mathrm{Ng}$ et al. 2020). Hence, improvement motivation may have instrumental value for the person because it promotes outcomes that are prudentially good. Moreover, when people acquire skills, this allows them to invest these skills into 


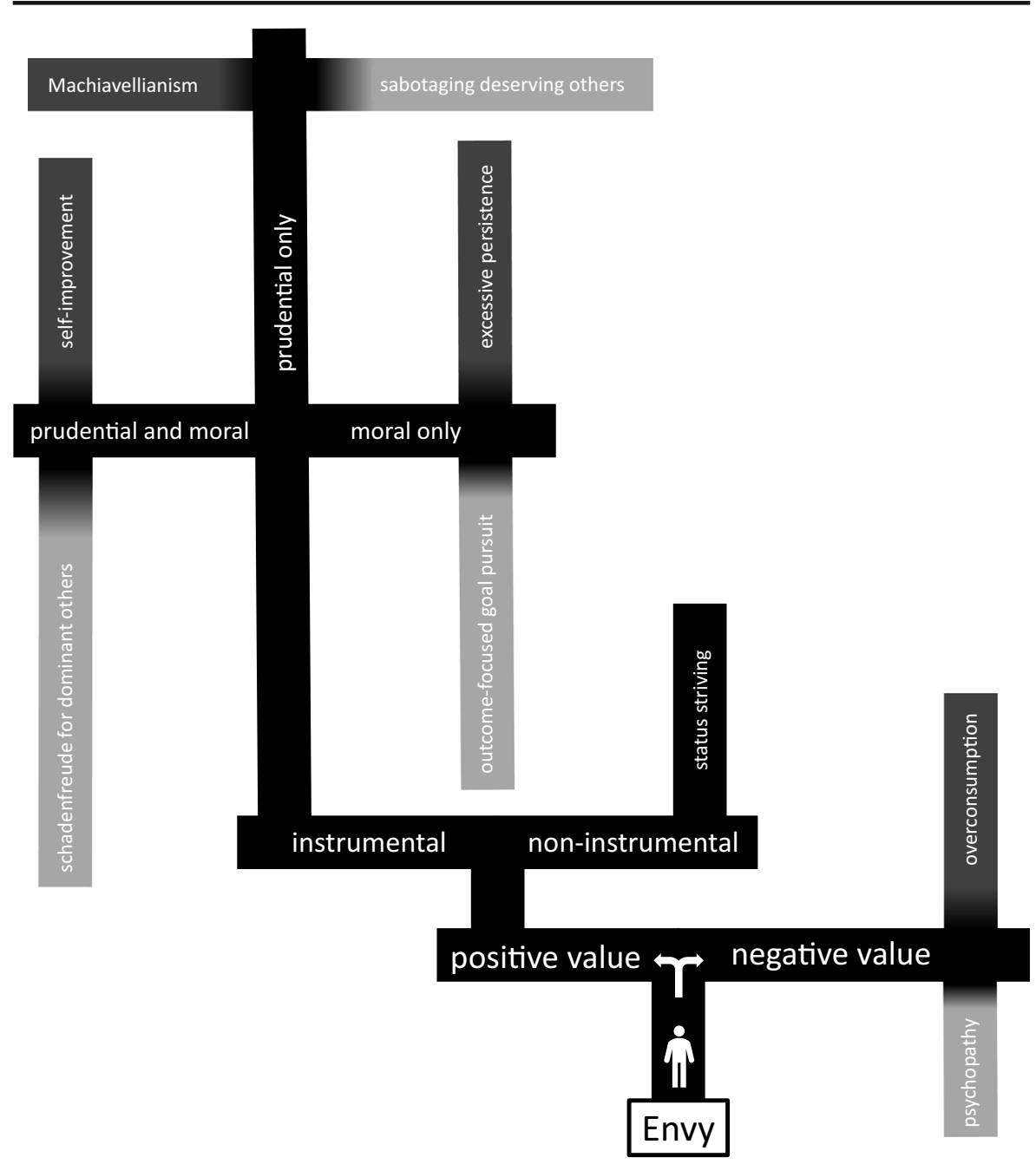

Fig. 1 The pathways of envy that have different value. Pathways that end in dark grey comers represent exemplary outcomes of benign envy and pathways that end in light grey corners represent exemplary outcomes of malicious envy

society, for instance in prestige hierarchies (Henrich and Gil-White 2001). Finally, when benign envy is felt with regard to morally good traits and qualities, the envier's improvement is not only prudentially good, but also valuable for others around them. Hence, social groups may benefit from benignly envious individuals in the long term, which means that benign envy may have instrumental moral value.

For malicious envy, evidence indicates that it triggers schadenfreude when arrogant high-achievers fail, changing the public image of these high-achievers and putting them in their place (Lange and Boecker 2019). Because this consequence leads to potentially lasting pleasure for the envier, it is prudentially good (Fletcher 2008). Moreover, arrogant high-achievers are widely disliked and spread fear among subordinates (Cheng et al. 2013; Maner and Case 2016). Therefore, putting such high-achievers in 
their place may benefit society at large (except for the high-achiever him-/herself) and is accordingly morally good, provided that no other countervailing harm is brought about.

Second, envy may have prudential, but not moral, instrumental value. For benign envy, evidence indicates that it relates to Machiavellian tendencies such as backstabbing (Lange et al. 2018b). Under certain conditions, these tendencies indeed correlate with higher status, for instance in the workplace (Shultz 1993; Hawley 2003; Lange et al. 2018b). High status, in turn, is a strong predictor of higher well-being (Anderson et al. 2015) rendering the envy-driven Machiavellian tendencies instrumental in achieving a prudentially good outcome. However, Machiavellian tendencies also relate to various antisocial behaviors that lead to interpersonal conflict (Muris et al. 2017). Therefore, under these conditions, the envy-driven Machiavellian tendencies are morally bad.

For malicious envy, there is less evidence in this category. One example may come from studies showing that malicious envy predicts the assignment of rather difficult tasks to an envied person who deservedly outperformed the envier in previous circumstances (Lange and Crusius 2015a). Under the assumption that these more difficult tasks will undermine the envied person's chances to continue being successful, assigning a more difficult task may — at least in the short-term — increase the envier's well-being, rendering such efforts instrumental in promoting an outcome that is prudentially good. However, as the envied person earned the success, moral observers should actually experience pleasure for the envied person (Feather 2006). If they instead assign more difficult tasks to these deserving others, doing so is morally bad. Even though the empirical evidence on the prudential benefits of malicious envy may be lacking, it is plausible that there can be several short-term advantages stemming from causing harm to the envied person. If that wasn't the case, we would expect much fewer cases of cheating, stealing, sabotaging and even murdering, all of which can sometimes be motivated by malicious envy. While these behaviors are socially stigmatized, legally sanctioned, and morally condemned, they do bring prudential benefits at least temporarily. When the envier's deeds remain undetected and permanently lower the standing of the envied person, it is even imaginable that the prudential benefits last for long periods of time.

Third, envy may have moral, but not prudential, instrumental value. For benign envy, evidence indicates that it leads to persistence, even when the task at hand is extremely difficult or potentially impossible to solve (Lange and Crusius 2015a). Persistence for impossible tasks will undermine the envier's well-being, which is prudentially bad. However, general persistence for extremely difficult tasks may produce success that could benefit society (Duckworth et al. 2007), rendering persistence instrumental in fostering morally good outcomes.

For malicious envy, evidence indicates that it triggers outcome-focused (i.e., effort-independent) goal-pursuit (Salerno et al. 2019), potentially motivating enviers to buy other luxury products similar to the kind that made them envious (Van de Ven et al. 2011b). Such alternative purchases fail to close the gap in the exact domain that elicited envy and fail to pull the envied person down. Accordingly, malicious enviers may often remain inferior, potentially explaining why malicious envy relates to lower well-being (Briki 2019; Ng et al. 2020), an outcome that is prudentially bad. However, buying alternative products still propels the economy, which benefits all people in the long-term. Therefore, this goal-pursuit may be instrumental in promoting outcomes that are arguably morally good. 
Along a second pathway, envy may have non-instrumental value in that it motivates the envier to pursue some goals for their own sake. Specifically, envy may have noninstrumental prudential and moral value. The central psychological goal underlying both benign and malicious envy is the regulation of social status (e.g., Crusius and Lange 2017). Evidence indicates that benign and malicious envy predict status attainment via different strategies (e.g., Lange et al. 2016; Lange et al. 2018b). Social status has diverse advantages for the self and contributes widely to the structuring and flourishing of society (e.g., Anderson et al. 2015). While this flourishing may be valuable instrumentally, some of it seems to be good for its own sake: it feels good to be the object of social esteem and approbation. Status is thus a thing that people often pursue for their own sake, as a component of their emotional well-being. As envy - at its core-is concerned with the pursuit and attainment of status, we would argue that envy may have prudential and moral non-instrumental value (for a related argument see La Caze 2001; Thomason 2015). From a philosophical perspective, dispositional benign envy, if it motivates to self-improve with regard to objectively valuable objects, may be considered a component of a virtuous character (Protasi 2021) and thus has prudential and moral non-instrumental value.

Along a third pathway, envy predicts outcomes that are prudentially and morally bad, in line with the common portrayal of envy. In this case, envy lacks value. For benign envy, evidence shows that it relates to overconsumption (Belk 2011). Because overconsumption may ruin people financially and also exploit the environment (de Graff et al. 2014), outcomes of overconsumption are prudentially and morally bad (see also Morgan-Knapp 2014). For malicious envy, evidence shows that it relates to psychopathic tendencies such as erratic and criminal behavior (Lange et al. 2018b). The same research indicates that these behaviors fail to translate into status, and, accordingly, fail to advance the envier's well-being longitudinally. Moreover, psychopathic tendencies generally predict negative long-term social effects (LeBreton et al. 2006) and interpersonal difficulties (Muris et al. 2017). Hence, the outcomes of envydriven psychopathic behaviors are prudentially and morally bad.

\subsection{Summary of the Value of Envy}

In sum, components and outcomes of envy derived from a functional perspective allow evaluating the value of envy in a more nuanced manner according to different dimensions. Envy may have instrumental value, as it promotes outcomes that are prudentially and morally good, prudentially good but morally bad, or morally good and prudentially bad. Moreover, envy may have non-instrumental value, being prudentially and morally good itself. However, envy is also often prudentially and morally bad. This more elaborate perspective on the value of envy has a number of implications.

\section{Implications of the Nuanced Perspective on the Value of Envy}

The current arguments provide a comprehensive perspective on the value of envy. They indicate that envy is not as reprehensible as commonly portrayed in public discourse. Moreover, envy is not, as argued in psychology and philosophy, morally bad (Roberts 1991; Miceli and Castelfranchi 2007), morally neutral and devoid of moral evaluations (Ben-Ze'ev 2002; Crusius et al. 2020), or morally good (Thomason 2015). Instead, 
evidence gathered from a functional perspective on envy shows that envy can be all of these things, depending on which dimension of value and which outcome of benign or malicious envy one applies under which conditions. Thus, a nuanced perspective on envy's nature leads to a nuanced perspective on envy's value, which in turn can help determine the most appropriate ways of responding to and coping with envy.

Any kind of envy has an important signaling value. That is, envy tells the agent what they might care about, whether they realize it or not (Protasi 2021). But, once the envier realizes they are envious, many possible modes of action become available to them (i.e., the different pathways in Fig. 1). Sometimes, envy is best coped with indirectly. If overcoming one's disadvantage is perceived as unlikely, the envier should try to reevaluate their situation: is the envied good really something to be valued? This need not be an instance of cognitive dissonance or sour grapes syndrome. Instead, sometimes, through reflection, we may realize that we envy people for bad reasons, and we should find more valuable goals. When feeling malicious envy, which is often morally bad, one possibility is to try and see the envied person in a more sympathetic light (Exline and Zell 2008). Specifically, perhaps we can bring ourselves to think of the envied person as a model to emulate, and develop feelings of benign envy, which is less likely to give rise to morally bad outcomes under most conditions. Sometimes envy can be so intense and malicious that the only possible ethical option is to repress it or at least to not act on it.

Moreover, the nuanced perspective on the value of envy also has implications for how envy is portrayed at the societal level. As outlined repeatedly, public discourse commonly portrays envy as a deadly sin, an emotion to be avoided. Accordingly, people often feel ashamed for their envy and judge enviers negatively, furthering the negative sentiment towards envy. The nuanced perspective on the value of envy instead implies that such evaluations should be contextualized. Envy need not be condemned unequivocally. Instead, under certain condition, a society may even embrace and nurture envy. A comprehensive discussion of envy's remedies cannot be pursued here. However, we hope that those who worry about the potential harms brought about by envy, from clinical psychologists and counselors to moral and political philosophers, focus both on the diverse nature of these harms, as much as their potential benefits (for an example see Leahy 2020).

Accomplishing such a balanced perspective requires more research on the contextualized nature of the value of envy. For many outcomes of envy, we can only tentatively suggest that envy may have certain kind of value. For instance, we argued that putting arrogant high achievers in their place by expressing schadenfreude is an effect of malicious envy that may be instrumental in producing prudentially and morally good outcomes. Indeed, research indicates that the negative feelings that trigger schadenfreude may be particularly strong when the low-status person resents their own situation (Feather and Nairn 2005). Hence, under low deservingness of the own situation, schadenfreude may be an indicator of negative feelings toward oneself, rendering this outcome prudentially bad. Moreover, when the high achiever deserved their initial high status, most people experience sympathy when the high achiever befalls a misfortune (Feather 2006). Accordingly, when one low-status person expresses schadenfreude, such an outcome would be regarded as morally bad by other observers. Therefore, the deservingness of the status of all involved persons constitutes an important contextual variable that affects the value of envy. For the other cases we discussed, future research should similarly investigate important boundary conditions. 
Finally, we hope that future interdisciplinary research may contribute to further refinement of an axiological theory of envy. Especially the pathway to the instrumental value of envy could become even more nuanced given the functional approach to envy. For instance, the case in which envy is instrumental for promoting outcomes that are prudentially bad but morally good did not receive much empirical investigation in the past. This might be of particular interest to utilitarian approaches to public policy. Perhaps moderate levels of dysfunctional benign envy at the individual level may nonetheless be productive at the societal level. Moreover, we are not aware of much research on malicious envy being instrumental for promoting outcomes that are prudentially good but morally bad. This may turn out not to occur frequently, which would be good news for the moralist. That is, it may be the case that malicious envy is truly the deadly sin that has been traditionally depicted. But it would be worthwhile to find empirical confirmation of this intuition. We urge researchers to investigate these cases further.

\section{Conclusions}

For a long time, envy has been considered to be reprehensible and therefore dispensable as a human experience. However, descriptions of the nature of envy require a more open-minded and comprehensive interdisciplinary approach. Recent empirical research infused with a philosophically discerning approach to value reveals that envy can be functional or dysfunctional, prudentially or morally good, depending on its variety and the present conditions. We hope that this nuanced perspective on the value of envy paints a more comprehensive picture, facilitating future theoretical and empirical research on envy and other emotions as well as informing public opinion.

Acknowledgements Ideas developed in this manuscript originated from a conference on Hostile Emotions hosted by Thiemo Breyer at the Center for Interdisciplinary Research of the University of Bielefeld. We thank Olivia Bailey and Jan Crusius for comments on a previous draft.

Availability of Data and Material not applicable.

Funding Open Access funding enabled and organized by Projekt DEAL. The research reported in this article was supported by grants from the German Research foundation (DFG; Deutsche Forschungsgemeinschaft) awarded to Jens Lange (LA 4029/1-1, LA 4029/2-1).

\section{Declarations}

Conflict of Interest The authors declare that they have no conflict of interest.

Open Access This article is licensed under a Creative Commons Attribution 4.0 International License, which permits use, sharing, adaptation, distribution and reproduction in any medium or format, as long as you give appropriate credit to the original author(s) and the source, provide a link to the Creative Commons licence, and indicate if changes were made. The images or other third party material in this article are included in the article's Creative Commons licence, unless indicated otherwise in a credit line to the material. If material is not included in the article's Creative Commons licence and your intended use is not permitted by statutory regulation or exceeds the permitted use, you will need to obtain permission directly from the copyright holder. To view a copy of this licence, visit http://creativecommons.org/licenses/by/4.0/. 


\section{References}

Anderson, Cameron, John Angus D. Hildreth, and Laura Howland. 2015. Is the desire for status a fundamental human motive? A review of the empirical literature. Psychological Bulletin 141: 574-601. https://doi.org/ 10.1037/a0038781.

Aquaro, G.R.A. 2004. Death by envy: The evil eye and envy in the Christian tradition. Lincoln: Universe.

Aristotle. 1925. The Nicomachean ethics. New York: Oxford University Press.

Aristotle. 1929. Art of rhetoric. Cambridge: Harvard University Press.

Bankovsky, Miriam. 2018. Excusing economic envy: On injustice and impotence. Journal of Applied Philosophy 35: 257-279. https://doi.org/10.1111/japp.12194.

Behler, Anna Maria C., Catherine S.J. Wall, Adriana Bos, and Jeffrey D. Green. 2020. To help or to harm? Assessing the impact of envy on prosocial and antisocial behaviors. Personality and Social Psychology Bulletin 014616721989766: 1156-1168. https://doi.org/10.1177/0146167219897660.

Belk, Russell. 2011. Benign envy. AMS Review 1: 117-134. https://doi.org/10.1007/s13162-011-0018-x.

Ben-Ze'ev, Aaron. 2002. Are envy, anger, and resentment moral emotions? Philosophical Explorations 5: 148-154. https://doi.org/10.1080/10002002058538728.

Briki, Walid. 2019. Harmed trait self-control: Why do people with a higher dispositional malicious envy experience lower subjective wellbeing? A cross-sectional study. Journal of Happiness Studies 20: 523540. https://doi.org/10.1007/s10902-017-9955-x.

Cheng, Joey T., Jessica L. Tracy, Tom Foulsham, Alan Kingstone, and Joseph Henrich. 2013. Two ways to the top: Evidence that dominance and prestige are distinct yet viable avenues to social rank and influence. Journal of Personality and Social Psychology 104: 103-125. https://doi.org/10.1037/a0030398.

Clore, Gerald L., and Andrew Ortony. 2013. Psychological construction in the OCC model of emotion. Emotion Review 5: 335-343. https://doi.org/10.1177/1754073913489751.

Cohen-Charash, Yochi. 2009. Episodic envy. Journal of Applied Social Psychology 39: 2128-2173. https:// doi.org/10.1111/j.1559-1816.2009.00519.x.

Cohen-Charash, Yochi, and E. Larson. 2017. An emotion divided: Studying envy is better than studying "benign" and "malicious" envy. Current Directions in Psychological Science 26: 174-183. https://doi. org/10.1177/0963721416683667.

Colombo, Matteo, Leandra Bucher, and Yoel Inbar. 2016. Explanatory judgment, moral offense and valuefree science. Review of Philosophy and Psychology 7: 743-763. https://doi.org/10.1007/s13164-0150282-z.

Coricelli, G., and A. Rustichini. 2009. Counterfactual thinking and emotions: Regret and envy learning. Philosophical Transactions of the Royal Society B: Biological Sciences 365: 241-247. https://doi.org/10. 1098/rstb.2009.0159.

Crusius, Jan, Manuel F. Gonzalez, Jens Lange, and Yochi Cohen-Charash. 2020. Envy: An adversarial review and comparison of two competing views. Emotion Review 12: 3-21. https://doi.org/10.1177/ 1754073919873131.

Crusius, Jan, and Jens Lange. in press. Counterfactual thoughts distinguish benign and malicious envy. Emotion.

Crusius, Jan, and Jens Lange. 2014. What catches the envious eye? Attentional biases within malicious and benign envy. Journal of Experimental Social Psychology 55: 1-11. https://doi.org/10.1016/j.jesp.2014. 05.007.

Crusius, Jan, and Jens Lange. 2017. How do people respond to threatened social status? Moderators of benign versus malicious envy. In Envy at work and in organizations: Research, theory, and applications, ed. R.H. Smith, U. Merlone, and M.K. Duffy, 85-110. New York: Oxford University Press.

Crusius, Jan, and Thomas Mussweiler. 2012. When people want what others have: The impulsive side of envious desire. Emotion 12: 142-153. https://doi.org/10.1037/a0023523.

D’Arms, Justin. 2018. Envy. Edited by E. N. Zalta. Stanford Encyclopedia of Philosophy.

D'Arms, Justin, and Daniel Jacobson. 2000. The moralistic fallacy: On the "appropriateness" of emotions. Philosophy and Phenomenological Research 61: 65. https://doi.org/10.2307/2653403.

D’Arms, Justin, and A.D. Kerr. 2008. Envy in the philosophical tradition. In Envy: Theory and research, R. H. Smith, 39-59. New York: Oxford University Press.

Duckworth, Angela L., Christopher Peterson, Michael D. Matthews, and Dennis R. Kelly. 2007. Grit: Perseverance and passion for long-term goals. Journal of Personality and Social Psychology 92: 10871101. https://doi.org/10.1037/0022-3514.92.6.1087. 
Duffy, M.K., K.L. Scott, J.D. Shaw, B.J. Tepper, and K. Aquino. 2012. A social context model of envy and social undermining. Academy of Management Journal 55: 643-666. https://doi.org/10.5465/amj.2009. 0804.

Duffy, M.K., and J.D. Shaw. 2000. The Salieri syndrome: Consequences of envy in groups. Small Group Research 31: 3-23. https://doi.org/10.1177/104649640003100101.

Ellsworth, Phoebe C., and Klaus R. Scherer. 2003. Appraisal processes in emotion. In Handbook of affective sciences, ed. Richard J. Davidson, Klaus R. Scherer, and H. Hill Goldsmith, 572-595. New York: Oxford University Press.

Exline, Julie J., and Anne L. Zell. 2008. Antidotes to envy: A conceptual framework. In Envy: Theory and research, ed. R.H. Smith, 315-331. New York: Oxford University Press.

Falcon, Rachael G. 2015. Is envy categorical or dimensional? An empirical investigation using taxometric analysis. Emotion 15: 694-698. https://doi.org/10.1037/emo0000102.

Feather, N.T. 2006. Deservingness and emotions: Applying the structural model of deservingness to the analysis of affective reactions to outcomes. European Review of Social Psychology 17: 38-73. https://doi. org/10.1080/10463280600662321.

Feather, N.T., and Katherine Nairn. 2005. Resentment, envy, schadenfreude, and sympathy: Effects of own and other's deserved or undeserved status. Australian Journal of Psychology 57: 87-102. https://doi.org/ $10.1080 / 00049530500048672$.

Fischer, A.H., and A.S.R. Manstead. 2016. Social functions of emotion and emotion regulation. In Handbook of emotions, ed. L.F. Barrett, M. Lewis, and J.M. Haviland-Jones, 424-439. New York: Guilford Press.

Fischer, A.H., and Ira J. Roseman. 2007. Beat them or ban them: The characteristics and social functions of anger and contempt. Journal of Personality and Social Psychology 93: 103-115. https://doi.org/10.1037/ 0022-3514.93.1.103.

Fiske, Susan T. 2010. Envy up, scorn down: How comparison divides us. American Psychologist 65: 698706. https://doi.org/10.1037/0003-066X.65.8.698.

Fletcher, Guy. 2008. The consistency of qualitative hedonism and the value of (at least some) malicious pleasures. Utilitas 20: 462-471. https://doi.org/10.1017/S0953820808003270.

Gino, Francesca, and Lamar Pierce. 2009. The abundance effect: Unethical behavior in the presence of wealth. Organizational Behavior and Human Decision Processes 109: 142-155. https://doi.org/10.1016/j.obhdp. 2009.03.003.

Glatz, Carol. 2014. All wars begin in a jealous heart; let go of pride, envy, pope says.

Glick, P. 2002. Sacrificial lambs dressed in wolves' clothing: Envious prejudice, ideology, and the scapegoating of Jews. In Understanding genocide: The social psychology of the holocaust, ed. L.S. Newman and R. Erber, 113-142. New York: Oxford University Press.

de Graff, J., D. Wann, and T.N. Naylor. 2014. Affluenza: How overconsumption is killing us - and how we can fight back. San Francisco: Berret-Koehler Publishers Inc..

Green, Jeffrey Edward. 2013. Rawls and the forgotten figure of the most advantaged: In defense of reasonable envy toward the superrich. American Political Science Review 107: 123-138. https://doi.org/10.1017/ S0003055412000585.

Hawley, Patricia H. 2003. Prosocial and coercive configurations of resource control in early adolescence: A case for the well-adapted Machiavellian. Merrill-Palmer Quarterly 49: 279-309. https://doi.org/10.1353/ mpq.2003.0013.

Heider, F. 1958. The psychology of interpersonal relations. Hillsdale: Lawrence Erlbaum Associates.

Henniger, Nicole E., and Christine R. Harris. 2015. Envy across adulthood: The what and the who. Basic and Applied Social Psychology 37: 303-318. https://doi.org/10.1080/01973533.2015.1088440.

Henrich, Joseph, and Francisco J. Gil-White. 2001. The evolution of prestige: Freely conferred deference as a mechanism for enhancing the benefits of cultural transmission. Evolution and Human Behavior 22: 165196. https://doi.org/10.1016/S1090-5138(00)00071-4.

Hume, D. 1969. A treatise of human nature. London: Penguin.

Hursthouse, R. 1999. On virtue ethics. Oxford: Oxford University Press.

Inbar, Y., and J. Lammers. 2012. Political diversity in social and personality psychology. Perspectives on Psychological Science 7: 496-503. https://doi.org/10.1177/1745691612448792.

Keltner, Dacher, and Jonathan Haidt. 1999. Social functions of emotions at four levels of analysis. Cognition \& Emotion 13: 505-521. https://doi.org/10.1080/026999399379168.

Khan, Abdul Karim, Chris M. Bell, and Samina Quratulain. 2017. The two faces of envy: Perceived opportunity to perform as a moderator of envy manifestation. Personnel Review 46: 490-511. https:// doi.org/10.1108/PR-12-2014-0279.

Kim, Eugene, and Theresa M. Glomb. 2014. Victimization of high performers: The roles of envy and work group identification. Journal of Applied Psychology 99: 619-634. https://doi.org/10.1037/a0035789. 
Kwiatkowska, Maria Magdalena, Radosław Rogoza, and Tatiana Volkodav. 2018. Psychometric properties of the Benign and Malicious Envy Scale: Assessment of structure, reliability, and measurement invariance across the United States, Germany, Russia, and Poland. Preprint. PsyArXiv. https://doi.org/10.31234/osf. io/7wutz.

Kwon, M., Y. Han, and M. Nam. 2017. Envy takes you further: The influence of benign envy on risk taking. Social Behavior and Personality 45: 39-50. https://doi.org/10.2224/sbp.5977.

La Caze, Marguerite. 2001. Envy and resentment. Philosophical Explorations 4: 31-45. https://doi.org/10. 1080/13869790108523341.

Lange, Jens, Lisa Blatz, and Jan Crusius. 2018a. Dispositional envy: A conceptual review. In SAGE handbook of personality and individual differences, ed. Virgil Zeigler-Hill and T.K. Shackelford, 424-440. Thousand Oaks: SAGE.

Lange, Jens, and Lea Boecker. 2019. Schadenfreude as social-functional dominance regulator. Emotion 19: 489-502. https://doi.org/10.1037/emo0000454.

Lange, Jens, J. Crusius, and Birk Hagemeyer. 2016. The evil Queen's dilemma: Linking narcissistic admiration and rivalry to benign and malicious envy. European Journal of Personality 30: 168-188. https://doi.org/10.1002/per.2047.

Lange, Jens, and Jan Crusius. 2015a. The tango of two deadly sins: The social-functional relation of envy and pride. Journal of Personality and Social Psychology 109: 453-472. https://doi.org/10.1037/pspi0000026.

Lange, Jens, and Jan Crusius. 2015b. Dispositional envy revisited: Unraveling the motivational dynamics of benign and malicious envy. Personality and Social Psychology Bulletin 41: 284-294. https://doi.org/10. $1177 / 0146167214564959$.

Lange, Jens, Delroy L. Paulhus, and Jan Crusius. 2018b. Elucidating the dark side of envy: Distinctive links of benign and malicious envy with dark personalities. Personality and Social Psychology Bulletin 44: 601614. https://doi.org/10.1177/0146167217746340.

Lange, Jens, Liz Redford, and Jan Crusius. 2019. A status-seeking account of psychological entitlement. Personality and Social Psychology Bulletin 45: 1113-1128. https://doi.org/10.1177/0146167218808501.

Lange, Jens, Aaron C. Weidman, and Jan Crusius. 2018c. The painful duality of envy: Evidence for an integrative theory and a meta-analysis on the relation of envy and schadenfreude. Journal of Personality and Social Psychology 114: 572-598. https://doi.org/10.1037/pspi0000118.

Leahy, Robert L. 2020. Cognitive-behavioral therapy for envy. Cognitive Therapy and Research. https://doi. org/10.1007/s10608-020-10135-y.

LeBreton, J.M., J.F. Binning, and A.J. Adorno. 2006. Subclinical psychopaths. In Comprehensive handbook of personality and psychopathology, ed. J.C. Thomas and D. Segal, 388-411. New York: Wiley.

Maner, J.K., and C.R. Case. 2016. Dominance and prestige: Dual strategies for navigating social hierarchies. In Advances in Experimental Social Psychology, ed. James M. Olson and mark P. Zanna, 54:129-180. Elsevier.

Mattes, Josef. 2019. Reports of the death of value-free science are greatly exaggerated. Review of Philosophy and Psychology 10: 689-699. https://doi.org/10.1007/s13164-018-0426-z.

McDowell, J. 1979. Virtue and reason. The Monist 62: 331-350.

Miceli, Maria, and Cristiano Castelfranchi. 2007. The envious mind. Cognition \& Emotion 21: 449-479. https://doi.org/10.1080/02699930600814735.

Moran, Simone, and Maurice E. Schweitzer. 2008. When better is worse: Envy and the use of deception. Negotiation and Conflict Management Research 1: 3-29. https://doi.org/10.1111/j.1750-4716.2007. 00002.x.

Morgan-Knapp, Christopher. 2014. Economic envy. Journal of Applied Philosophy 31: 113-126. https://doi. org/10.1111/japp.12045.

Muris, Peter, Harald Merckelbach, Henry Otgaar, and Ewout Meijer. 2017. The malevolent side of human nature: A meta-analysis and critical review of the literature on the dark triad (narcissism, Machiavellianism, and psychopathy). Perspectives on Psychological Science 12: 183-204. https://doi. org/10.1177/1745691616666070.

Ng, Jacky C.K., K.Y. Au Algae, Helen S.M. Wong, Carmen K.M. Sum, and Victor C.Y. Lau. 2020. Does dispositional envy make you flourish more (or less) in life? An examination of its longitudinal impact and mediating mechanisms among adolescents and young adults. Journal of Happiness Studies. 22: 10891117. https://doi.org/10.1007/s10902-020-00265-1.

Parrott, W.G. 1991. The emotional experiences of envy and jealousy. In The psychology of jealousy and envy, ed. Peter Salovey, 3-30. New York: Guilford Press.

Parrott, W.G., and R.H. Smith. 1993. Distinguishing the experiences of envy and jealousy. Journal of Personality and Social Psychology 64: 906-920. https://doi.org/10.1037/0022-3514.64.6.906. 
Protasi, Sara. 2016. Varieties of envy. Philosophical Psychology 29: 535-549. https://doi.org/10.1080/ 09515089.2015.1115475.

Protasi, Sara. 2019. Happy self-surrender and unhappy self-assertion: A comparison between admiration and emulative envy. In The moral psychology of admiration, ed. Alfred Archer and A. Grahle, 45-60. London: Rowman \& Littlefield.

Protasi, Sara. 2021. The philosophy of envy. Cambridge: Cambridge University Press.

Razzetti, G. 2018. How to avoid jealousy and envy from poisoning your life.

Roberts, Robert C. 1991. What is wrong with wicked feelings? American Philosophical Quarterly 28: 13-24.

Salerno, Anthony, Juliano Laran, and Chris Janiszewski. 2019. The bad can be good: When benign and malicious envy motivate goal pursuit. Journal of Consumer Research 46: 388-405. https://doi.org/10. 1093/jcr/ucy077.

Salovey, Peter, and Judith Rodin. 1984. Some antecedents and consequences of social-comparison jealousy. Journal of Personality and Social Psychology 47: 780-792. https://doi.org/10.1037/0022-3514.47.4.780.

Salovey, Peter, and Judith Rodin. 1986. The differentiation of social-comparison jealousy and romantic jealousy. Journal of Personality and Social Psychology 50: 1100-1112. https://doi.org/10.1037/00223514.50.6.1100.

Sawada, Masato, and Tsutomu Fujii. 2016. Do envious people show better performance?: Focusing on the function of benign envy as personality trait. The Japanese journal of psychology 87: 198-204. https://doi. org/10.4992/jjpsy.87.15316.

Sayers, D.L. 1947. Creed or chaos?: And other essays in popular theology. London: Metheuen and Co..

Schaubroeck, John, and Simon S.K. Lam. 2004. Comparing lots before and after: Promotion rejectees' invidious reactions to promotees. Organizational Behavior and Human Decision Processes 94: 33-47. https://doi.org/10.1016/j.obhdp.2004.01.001.

Schoeck, H. 1969. Envy: A theory of social behavior. New York: Harcourt, Brace \& World.

Shultz, Clifford J. 1993. Situational and dispositional predictors of performance: A test of the hypothesized Machiavellianism structure interaction among sales persons. Journal of Applied Social Psychology 23: 478-498. https://doi.org/10.1111/j.1559-1816.1993.tb01099.x.

Sidgwick, H. 1967. The methods of ethics. London: Macmillan.

Silver, Maury, and John Sabini. 1978. The perception of envy. Social Psychology 41: 105-117. https://doi.org/ $10.2307 / 3033570$.

Smallets, Stephanie, Lindsey Streamer, Cheryl L. Kondrak, and Mark D. Seery. 2016. Bringing you down versus bringing me up: Discrepant versus congruent high explicit self-esteem differentially predict malicious and benign envy. Personality and Individual Differences 94: 173-179. https://doi.org/10. 1016/j.paid.2016.01.007.

Smith, R.H. 2014. The joy of pain: Schadenfreude and the dark side of human nature. New York: Oxford University Press.

Smith, R.H., and Sung Hee Kim. 2007. Comprehending envy. Psychological Bulletin 133: 46-64. https://doi. org/10.1037/0033-2909.133.1.46.

Sterling, C.M., N. Van de Ven, and R.H. Smith. 2017. The two faces of envy: Studying benign and malicious envy in the workplace. In Envy at work and in organizations, ed. R.H. Smith, U. Merlone, and Michelle Duffy, 57-84. New York: Oxford University Press.

Tai, K., J. Narayanan, and D.J. McAllister. 2012. Envy as pain: Rethinking the nature of envy and its implications for employees and organizations. Academy of Management Review 37: 107-129. https://doi. org/10.5465/amr.2009.0484.

Taylor, G. 2006. Deadly vices. New York: Oxford University Press.

Teigen, Karl Halvor. 1997. Luck, envy and gratitude: It could have been different. Scandinavian Journal of Psychology 38: 313-323. https://doi.org/10.1111/1467-9450.00041.

Thomason, Krista K. 2015. The moral value of envy. The Southern Journal of Philosophy 53: 36-53. https:// doi.org/10.1111/sjp.12095.

Van de Ven, Niels. 2016. Envy and its consequences: Why it is useful to distinguish between benign and malicious envy. Social and Personality Psychology Compass 10: 337-349. https://doi.org/10.1111/spc3. 12253.

Van de Ven, Niels, and Marcel Zeelenberg. 2015. On the counterfactual nature of envy: It could have been me. Cognition and Emotion 29: 954-971. https://doi.org/10.1080/02699931.2014.957657.

Van de Ven, Niels, Marcel Zeelenberg, and Rik Pieters. 2009. Leveling up and down: The experiences of benign and malicious envy. Emotion 9: 419-429. https://doi.org/10.1037/a0015669.

Van de Ven, Niels, M. Zeelenberg, and R. Pieters. 2011a. Why envy outperforms admiration. Personality and Social Psychology Bulletin 37: 784-795. https://doi.org/10.1177/0146167211400421. 
Van de Ven, Niels, Marcel Zeelenberg, and Rik Pieters. 2011b. The envy premium in product evaluation. The Journal of Consumer Research 37: 984-998. https://doi.org/10.1086/657239.

Van de Ven, Niels, Marcel Zeelenberg, and Rik Pieters. 2012. Appraisal patterns of envy and related emotions. Motivation and Emotion 36: 195-204. https://doi.org/10.1007/s11031-011-9235-8.

Van de Ven, Niels, Charles E. Hoogland, Richard H. Smith, Wilco W. van Dijk, Seger M. Breugelmans, and Marcel Zeelenberg. 2015. When envy leads to schadenfreude. Cognition and Emotion 29: 1007-1025. https://doi.org/10.1080/02699931.2014.961903.

Van Kleef, G.A. 2009. How emotions regulate social life: The emotions as social information (EASI) model. Current Directions in Psychological Science 18: 184-188. https://doi.org/10.1111/j.1467-8721.2009. 01633.x.

Vrabel, Jennifer K., Virgil Zeigler-Hill, and Ashton C. Southard. 2018. Self-esteem and envy: Is state selfesteem instability associated with the benign and malicious forms of envy? Personality and Individual Differences 123: 100-104. https://doi.org/10.1016/j.paid.2017.11.001.

Yusainy, Cleoputri, Ziadatul Hikmiah, Cathy Sofhieanty, and Muhammad Ibrahim. 2019. Deception in negotiation: The predicting roles of envy and individual differences. ANIMA Indonesian Psychological Journal 33: 203-212. https://doi.org/10.24123/aipj.v33i4.1794.

Zizzo, Daniel John, and Andrew J. Oswald. 2001. Are people willing to pay to reduce other's incomes? Annals of Economics and Statistics 63 (64): 39-65.

Publisher's Note Springer Nature remains neutral with regard to jurisdictional claims in published maps and institutional affiliations. 